\title{
Instituições jurídicas, propriedade fundiária e desenvolvimento econômico no pensamento de José Da Silva Lisboa (1829)
}

\author{
José Flávio Pereira \\ Lupércio Antônio Pereira*
}

\begin{abstract}
Resumo: Esse artigo analisa a posição política de José da Silva Lisboa, o Visconde de Cairu, no debate acontecido no parlamento brasileiro em 1829 acerca da abolição de duas instituições jurídicas feudais relacionadas à estrutura fundiária que haviam sido herdadas de Portugal: o Direito de Primogenitura e o Morgadio. Segundo Cairu, tais instituições, que obrigavam a transmissão da propriedade da terra para o filho primogênito masculino e impediam sua posterior subdivisão e alienação, existiam de forma muito enfraquecida no Brasil, não comprometendo, portanto, o desenvolvimento da agricultura nem a democratização da propriedade fundiária. Porém, quando a questão foi apreciada no Senado, Cairu articulou a votação vitoriosa contra a abolição dessas instituições, aparentemente contradizendo suas idéias de economista político liberal. Julgamos que a explicação para tal paradoxo estaria no pragmatismo e na prudência política de Cairu, que foi sempre avesso ao radicalismo quando enfrentou a questão da reforma da sociedade. Sua oposição, aparentemente antiliberal, à abolição de tais instituições deve-se ao fato de considerá-las importantes instrumentos simbólicos de preservação da monarquia ilustrada no Brasil. Este regime estaria mais próximo do modelo político inglês, que propunha ser imitado, e mais distante do republicanismo radical francês, que ele julgava que deveria ser evitado.
\end{abstract}

Palavras-chave: Cairu, propriedade fundiária, primogenitura, Brasil.

José da Silva Lisboa, mais conhecido como Visconde de Cairu (1756-1835), é considerado um dos pensadores mais influentes do mundo luso-brasileiro entre o final do século XVIII e as três primeiras décadas do século XIX. É reconhecido pela historiografia econômica como o introdutor formal da Economia Política no Brasil. Também é reconhecido como conselheiro influente junto à corte portuguesa, após a sua transmigração para o Brasil. Na qualidade de conselheiro prestigiado, Cairu teria sido um incentivador e o grande teórico do decreto de abertura dos portos do Brasil ao comércio mundial, assinado em 1808 por Dom João, Príncipe Regente do então Reino Unido de Brasil, Portugal e Algarves.

Em sintonia fina com os princípios daquela escola econômica, Cairu apoiou também, com todos os seus recursos teóricos de grande conhecedor da Economia 
Clássica, o decreto do Príncipe Regente revogando a Carta Régia que proibia a atividade manufatureira no Brasil.

O nome de Cairu está indissoluvelmente associado, portanto, à luta teórica travada no Brasil no início do século XIX, com vistas à remoção de todos os obstáculos que se interpunham ao livre-comércio, no plano internacional, e à livre iniciativa para os agentes econômicos, no plano interno.

Além de conselheiro real e escritor influente, Cairu foi, também, um atuante senador do Império, aspecto menos conhecido de sua rica biografia. Uma vez que sua atividade se concentrou nas três primeiras décadas do século XIX, ele acabou participando ativamente do processo de formação do Estado Nacional brasileiro, seja no campo teórico seja no campo político-prático.

É exatamente nessa atuação parlamentar que flagramos Cairu na defesa de posições que aparentemente o distanciariam dos princípios da Economia Política, vale dizer, do liberalismo econômico, como é o caso do caráter da propriedade da terra. Refletir sobre sua posição a respeito dessa importante questão é o objetivo deste artigo.

Nas discussões travadas sobre a questão agrária no Senado do Império do Brasil, surpreendemos Cairu numa posição que, em princípio, poderíamos chamar de contraditória ou ambígua e, no limite, conservadora. Nota-se, naqueles debates, que Cairu parecia se preocupar mais com a criação de mecanismos legais para se evitar a divisão excessiva da terra do que com a remoção de instituições herdadas do Feudalismo e do Antigo Regime e que, em princípio, poderiam opor obstáculos à livre circulação e à democratização da propriedade da terra, como os chamados bens vinculados, especialmente o morgadio e a lei de primogenitura.

Cabe, aqui, uma pergunta: por que, em relação às normas então vigentes relativas à propriedade da terra, Cairu não demonstrou a mesma oposição que manifestou em relação a outras heranças do Feudalismo e do Antigo Regime? É o que tentaremos responder neste trabalho.

A análise da posição de Cairu na discussão da legislação agrária para o Brasil necessita de um embasamento. Por isso, é conveniente fazer um breve balanço historiográfico dos principais estudos da obra de Cairu, além de uma discussão sobre as origens históricas do direito de primogenitura e do morgadio e da posição assumida diante dessas instituições por aquele que é considerado um dos fundadores da Economia Política Clássica, o escocês Adam Smith, do qual Cairu se julgava um discípulo. 
De início, é necessário assinalar que a obra de Cairu talvez esteja entre aquelas que mais controvérsias e polêmicas suscitam entre historiadores, economistas e comentaristas. Alguns historiadores, por exemplo, julgam a obra de Cairu como um sistema teórico-político conservador e passadista que estava mais comprometido com o nosso passado rural e colonial do que com as grandes transformações sociais em curso no século XIX. Os argumentos principais dos quais lançam mão para fundamentar tal tese são o monarquismo e a oposição tímida e tolerante de Cairu em relação à estrutura colonial de produção, especialmente a escravidão, a grande propriedade da terra e as instituições a ela ligadas. Perfilam, nessa linha interpretativa, com algumas diferenças entre si, Sérgio Buarque de Holanda, Déa Fenelon, Antônio Penalves Rocha, entre outros.

Segundo Buarque de Holanda, apesar das aparências, em 1819 Cairu "já era um homem do passado, comprometido na tarefa de, a qualquer custo, frustrar a liquidação das concepções e formas de vida relacionadas de algum modo ao nosso passado rural e colonial" (Holanda, 1976, p.53). O motivo desse julgamento é um escrito de Cairu, Ensaio econômico sobre o influxo da inteligência humana na riqueza e prosperidade das nações (Cairu, 1975), onde ele diz que a causa principal da riqueza e prosperidade das nações é o trabalho inteligente e não o trabalho mecânico, braçal e penoso. No seu entendimento, essa tese de Cairu expressaria simplesmente o conceito de talento vigente no meio rural colonial, escravocrata e latifundiário brasileiro, talento este mais relacionado ao simples exercício da inteligência abstrata e decorativa do que às atividades que requerem algum esforço físico. Cairu seria, assim, prisioneiro de um conceito de trabalho mental ou de inteligência que se identificava mais com ornamento e prenda do que instrumento de conhecimento e ação. Isso decorria de suas ilusões teóricas e de sua incapacidade para compreender que, numa sociedade de coloração aristocrática e personalista, como a brasileira, tal idéia de trabalho inteligente só pode servir politicamente para distinguir uma pequena parte dos indivíduos com base em "alguma virtude aparentemente congênita e intransferível, que é a nobreza de sangue" (Holanda, 1976, p.50-2).

Esta tese de Buarque de Holanda não é, entretanto, aceita por Déa Fenelon. Embora, como dissemos, ela veja traços políticos conservadores em Cairu, sua visão do pensamento deste autor é mais nuançada. Cairu personifica, segundo ela, um liberalismo oportunista e de ocasião temperado na luta contra o inimigo externo, a Metrópole portuguesa. Com base neste liberalismo, ele formula o seu projeto político de 
organização do estado nacional brasileiro. É aí que o passadismo e a timidez liberal deste economista se revelarão explicitamente, pois ao invés de se preocupar com a formulação de uma profunda reforma da estrutura colonial de produção, ele formulará uma ideologia destinada a encobrir as contradições de um sistema liberal obrigado a coexistir com o regime monárquico absolutista, com a escravidão, com a grande propriedade rural etc. Até aí observamos uma grande proximidade de pontos de vista de Déa Fenelon com Buarque de Holanda. Mas, quando se trata de julgar a tese de Cairu sobre o trabalho inteligente, esta proximidade interpretativa diminui. Esta historiadora interpreta a idéia de trabalho inteligente de Cairu não simplesmente como prova da postura antimoderna deste economista baiano, mas como um indício das situações contraditórias e paradoxais com as quais letrados de classe média tinham que conviver numa sociedade escravista como a brasileira. Ela reconhece em Cairu o tipo clássico de burocrata citadino pertencente a um grupo social definido, mas sem ideais ou valores próprios, que é obrigado a viver inteiramente na dependência do estado. $\mathrm{O}$ resultado político natural desta sua situação leva-o a assumir, claramente, a posição da classe dominante, que, no Brasil, é composta pelos senhores rurais, o elemento mais tradicional (Fenelon, 1973).

Tal situação, entretanto, não impede que Cairu tente destacar o único valor com que conta o seu grupo social, que é a inteligência, já que é um grupo social não diretamente enquadrado no sistema de produção. Mas a categoria inteligência não tem, aqui, o mesmo sentido atribuído por Sérgio Buarque de Holanda, qual seja, o de exercício do espírito para fins de ostentação erudita e decorativa. Segundo Déa Fenelon, inteligência para Cairu tem o sentido de conhecimento prático e positivo destinado ao desenvolvimento do trabalho produtivo, ou seja, destinado ao "desenvolvimento das Artes e Ciências da Geral Indústria do país" (Fenelon, 1973, p.158) ${ }^{1}$.

Antônio Penalves Rocha, como mencionamos, é outro historiador que julga Cairu um autor conservador. Apesar disso, ele não absolutiza este conservadorismo de Cairu. Ao contrário, para Penalves Rocha, o economista baiano se moveria no interior de um quadro de contradições teórico-políticas, o que tornava o seu pensamento algo bastante nuançado. Cairu é identificado, inicialmente, com certo viés progressista, na medida em que propunha uma reformulação do papel do Estado, ou seja, propunha a substituição do Estado mercantilista por um Estado menos intervencionista e regulamentador. Este novo estado proposto por Cairu deveria unir o interesse do soberano ao interesse de seus súditos de uma maneira ampliada. Tal proposição 
demonstraria, segundo Penalves Rocha, um viés progressista de Cairu, pois ela tinha como objetivo fazer do Estado um aliado da ordem social, o que não tinha acontecido até então (Rocha, 1996).

Todavia, Penalves Rocha identifica uma contradição nas formulações de Cairu. Ao mesmo tempo em que ele propunha uma harmonia entre os interesses do soberano e os interesses dos súditos, defendia também a desigualdade natural, a propriedade e a liberdade econômica. Fazendo isso, Cairu estaria colocando sua teoria a favor do poder estatal e dos proprietários agrícolas, negando, portanto, a harmonia social e participando diretamente da luta de classes a favor da elite agrária. Isso teria sido possível com a adaptação que Cairu havia feito da economia política para aplicá-la ao estudo das questões brasileiras. Nesta adaptação, ele teria assumido um posicionamento liberal dúbio ou a meias, o que lhe permitia tratar da relação entre desenvolvimento industrial versus escravidão no Brasil de uma maneira inusitada. $\mathrm{O}$ inusitado, no caso, foi colocar a tese dos economistas políticos acerca da relação entre industrialização e escravidão de pernas para o ar. Na opinião de Rocha, enquanto os economistas diziam que a “escravidão devia ser extinta porque não despertava a motivação para o trabalho especializado, impedindo o desenvolvimento industrial", Cairu, por sua vez, se opunha a uma abolição imediata da escravidão ao mesmo tempo em que dizia que "as fábricas eram inexeqüíveis no Brasil em conseqüência da existência de escravos, o que vale dizer que a escravidão brasileira era inelutável", . Deste modo, Cairu, "para combater a instalação de fábricas no Brasil, adaptava uma idéia antiescravista a uma sociedade escravista e, ao mesmo tempo, fornecia subsídios ideológicos para a preservação de uma estrutura agrário-exportadora escravista da economia brasileira” (Rocha, 1996, p.123).

Mas, como já mencionamos, em torno do pensamento de Cairu criaram-se muitas controvérsias, gerando-se uma polêmica historiográfica, não faltando historiadores, economistas e comentaristas que o identificam com uma postura teórica progressista, comprometida com o processo de modernização da sociedade brasileira. Alguns deles, convencidos desse progressismo de Cairu, colocam-no em outro extremo interpretativo: o de precursor e antecipador de questões e teorias sociais específicas do século XX. É o caso de Alceu Amoroso Lima (1956), de Luis Nogueira de Paula (1956) e de José Almeida (1975). Preocupados em demonstrar a atualidade e a ação teórica precursora de Cairu, esses autores passam a vê-lo como teórico do pleno emprego keynesiano, da justiça social e do intervencionismo estatal na produção e distribuição da riqueza nacional. Podemos observar que o pressuposto teórico-político adotado por 
estes autores atualizadores para analisar a obra liberal de Cairu é, no fundo, a própria teoria keynesiana e sua doutrina social. Eles introjetam as concepções de Keynes na obra de Cairu e passam a extrair conclusões keynesianas do seu próprio interior. Estes são os estudiosos que poderíamos chamar de atualizadores do pensamento de Cairu.

Existem, ainda, aqueles estudiosos que procuram ver as idéias de Cairu como algo fora do lugar, ou seja, fora do contexto brasileiro. Antônio Paim (1968) é um exemplo representativo deste padrão interpretativo. Apesar disso, Paim está longe de considerar Cairu um pensador conservador e passadista. Ao invés de julgar o economista baiano como um autor voltado para o nosso passado rural e colonial, julgao como um pensador cujas idéias estão muito avançadas para as condições históricas brasileiras. Portanto, para Paim, o pensamento de Cairu está, em face do contexto brasileiro, mais para um projeto ousado e utópico de reforma da sociedade brasileira do que para um projeto político voltado para a perpetuação de nosso passado rural $e$ colonial.

Fazem parte, finalmente, desse rol heterogêneo de estudiosos aqueles autores que procuram demonstrar o caráter econômico progressista e avançado da obra cairuniana sem, no entanto, deslocá-la do contexto histórico em que foi produzida, ou seja, sem procurar atualizá-la ou vê-la como algo utópico e fora do lugar. Comungam essa linha interpretativa, com algumas diferenças entre si, os seguintes autores: Darcy Carvalho (1985), José Flávio Pereira (1994), José Jobson de Andrade Arruda e Fernando Novais (2003).

Uma das razões que movem Darcy Carvalho a estudar a obra de Cairu é o debate contemporâneo sobre a questão do subdesenvolvimento versus desenvolvimento econômico. Ele demonstra, assim, que também está levemente influenciado pela concepção atualizadora. Tal influência revela-se quando afirma, numa curta passagem de seu livro, que na obra de Cairu já se encontra a "perfeita consciência do problema do emprego e desemprego equacionado em terminologia atualíssima" (Carvalho, 1985, p.277). Apesar disso, o que notamos de mais marcante em seu estudo é a preocupação de situar historicamente Cairu e, ao mesmo tempo, caracterizá-lo como um economista desenvolvimentista comprometido com a prosperidade e o bem-estar material geral. $\mathrm{Na}$ sua avaliação, portanto, a liberdade industrial e comercial proposta por Cairu não poderia, como assinalavam outros autores, ser considerada mero instrumento de atendimento dos interesses exclusivistas dos proprietários de terra escravistas brasileiros do século XIX (Carvalho, 1985). 
No caso de José Flávio Pereira, seu estudo mostra que Cairu constrói o seu pensamento reformador em oposição a duas coisas. Por um lado, ele opõe-se à economia política inspirada em Rousseau, argumentando que se trata de um projeto romântico e excessivamente radical de reforma da sociedade, projeto este inspirado no padrão de homem primitivo, selvagem e pobre. Por outro, ele opõe-se a todas as instituições e sistemas teóricos considerados antinaturais que embaraçam e desestimulam o crescimento da riqueza, a saber: as instituições feudais, o sistema fisiocrático, o sistema mercantilista e a lei dos pobres. É, pois, a partir dessas considerações que Pereira chega à conclusão de que Cairu assumiu, em sua época, uma postura progressista, no sentido de lutar pela consolidação das relações sociais burguesas no momento em que estas se constituíam em oposição às instituições semifeudais e mercantilistas do Antigo Regime. Assinala Pereira que essa postura progressista inspirava-se no modelo inglês de reforma, menos radical e violento, e se contrapunha ao republicanismo radical francês inspirado no pensamento político de Rousseau. Segundo Pereira, tal singularidade do pensamento de Cairu permitiria ao historiador romper com o preconceito teórico e político que classifica a obra de Cairu como conservadora, reacionária, passadista, etc. (Pereira, 1994).

Finalmente, para encerrarmos esse balanço historiográfico, temos o estudo recente de José Jobson de Andrade Arruda e Fernando Novais (2003). Segundo eles, não há como negar o caráter revolucionário do pensamento de Cairu se o considerarmos como expressão do contexto histórico em que foi produzido. Este posicionamento progressista de Cairu se evidenciaria em vários momentos, como, por exemplo, no período de 1810 e 1815, quando ele mobiliza suas energias teóricas para defender determinadas reformas no Brasil e em Portugal como caminho para a constituição do Império Luso-Brasileiro. No evento da abertura dos portos, em 1808, também se manifestaria essa natureza progressista de Cairu. Ao escrever obras e discursar em defesa da liberdade portuária e comercial, ele não apenas reproduzia dogmaticamente, em terras luso-brasileiras, princípios econômicos liberais produzidos na Europa, mas também expressava que sua reflexão se produzia com base na conjunção desses princípios econômicos liberais com a observação das circunstâncias históricas específicas da sociedade brasileira. Subentende-se, pelo que dizem estes autores, que a abertura dos portos e a liberdade comercial, defendidas por Cairu em 1808, eram uma premente necessidade histórica para se evitar o aniquilamento da economia lusobrasileira, estrangulada pelo decadente mercantilismo português e pelo bloqueio 
comercial colocado em prática por Napoleão Bonaparte no continente europeu. No campo da política propriamente dita, esses dois historiadores assinalam que definir Cairu simplesmente como "um ideólogo do senhoriato brasileiro é descurar da questão essencial: a de que foi exatamente este estrato social que, bem ou mal, empenhava-se em organizar a nação". Cairu foi, sim, “o ideólogo do senhoriato brasileiro", mas não apenas isto, pois também pensou as condições possíveis para a construção do Estado Nacional (Arruda \& Novais, 2003).

Em face da polêmica historiográfica que se produziu em torno de Cairu e seu pensamento, acreditamos que o caminho para se aproximar de uma visão menos preconceituosa e menos subjetiva de suas concepções é voltarmos à própria obra de Cairu, à fonte documental, e tentar analisar essas concepções na relação direta com as condições sociais da época e com as questões concretas que Cairu e os contemporâneos tiveram de enfrentar e resolver. Sabemos nós que sua época foi uma época de rupturas históricas, rupturas estas que poderiam, no entanto, ser encaminhadas por meio de estratégias políticas diferentes.

Cairu expressou, como já mencionamos, a estratégia de mudanças sociais, econômicas e políticas adotada pelos ingleses e que encontramos tão bem expressada em obras de pensadores revolucionários como David Hume e Adam Smith. Esta estratégia era marcada pelo gradualismo político e pelo emprego moderado da força. Como bem mostrou Tocqueville, a chave explicativa do ritmo relativamente pacífico do processo histórico inglês é o caráter aberto da sociedade inglesa e o costume político de introduzir, com arte, as novas instituições no velho corpo social, sem correr o risco de dissolvê-lo, ou seja, "dando-lhe um novo vigor sem tirar-lhe as formas antigas" (Tocqueville, 1979). Cairu, frisamos, é a expressão dessa maneira de conceber as transformações sociais em terras brasileiras. Supomos, porém, que a oposição de Cairu ao radicalismo jacobino não pode ser classificada como reacionária, nostálgica e refratária às mudanças históricas que aconteciam em sua época. Nossa hipótese é de que Cairu militava política e intelectualmente a favor de mudanças substanciais na sociedade brasileira, mas fazia-o por um caminho próprio e seguindo uma trajetória não linear.

Esta postura cuidadosa e pragmática é evidente quando Cairu examina a questão da abolição do direito de primogenitura e do morgadio no Brasil. A análise desse posicionamento a partir de seus próprios escritos e dos dilemas do seu próprio tempo nos permitirá, portanto, irmos além das aparências e, assim, cotejar suas concepções 
com aquelas interpretações históricas que o classificam, sem nenhuma mediação, como um pensador conservador e passadista.

Feito este balanço historiográfico, é necessário, agora, examinarmos qual é a origem histórica do direito de primogenitura e do morgadio, bem como o posicionamento de Adam Smith, o inspirador teórico de Cairu, a respeito dessas duas instituições. Em seguida, trataremos do posicionamento de Cairu a respeito da questão e, ao final, estabeleceremos algumas breves relações entre este seu posicionamento e algumas interpretações históricas sobre seu pensamento.

Em A Riqueza das Nações, Smith fez severas críticas a essas instituições feudais. Entretanto, ressalve-se que essa crítica não foi absoluta nem incondicional, mas histórica. Tentemos traduzir o que isso significa.

Na concepção smithiana, a lei de primogenitura foi adotada na Europa medieval como resposta às desordens e à insegurança que se seguiram à queda do Império Romano. Segundo ele, com a queda do Império Romano sobreveio uma época de desordem generalizada na Europa e os únicos agentes capazes de oferecer alguma segurança aos habitantes do campo eram os grandes proprietários das terras. Assim, a terra deixou de ser considerada mero "meio de subsistência" e passou a ser concebida também como instrumento de poder e proteção. Naquela "época de desordem", todo grande proprietário de terras passou a ser "uma espécie de príncipe secundário" e "seus rendeiros eram seus súditos". Como cada grande senhor podia fazer "guerra a seu talante" contra seus vizinhos e até contra seu soberano, a insegurança era geral, de modo que "a proteção que seu proprietário tinha condições de oferecer aos que nela moravam, dependia da extensão da terra". Assim, a divisão da grande propriedade poderia colocar em risco a segurança dos seus moradores, que ficavam sujeitos às incursões de vizinhos belicosos. Por isso, continua o autor da Riqueza das Nações, "a lei de primogenitura veio a implantar-se gradualmente na sucessão das propriedades rurais, pela mesma razão pela qual geralmente se implantou na sucessão das monarquias", isto é, para que o poder do grande proprietário, e conseqüentemente a segurança que ele oferecia, não se enfraquecesse por divisões ${ }^{3}$. Para evitar essa divisão, adotou-se a norma de que a grande propriedade da nobreza fosse herdada apenas por um dos filhos, o mais velho, com precedência para o sexo masculino na linha de sucessão. Assim, impondo a sucessão linear ao invés da sucessão democrática, a primogenitura impedia que a grande propriedade fosse partilhada entre os herdeiros (Smith, 1983, v.I, p.325-6). 
Ainda segundo Smith, o morgadio, instituição desconhecida entre os romanos, foi adotado para complementar a lei de primogenitura. Se esta impedia a partilha dos domínios por meio da herança, aquele bloqueava a partilha por meio da alienação, legado ou doação. Para Smith, o morgadio foi uma "consequiência natural da lei da primogenitura" (idem, p.326) e combinava-se com ela para preservar a integridade da grande propriedade, julgada necessária para a preservação da segurança na época da "anarquia feudal".

Portanto, na formulação de Smith, era a "anarquia feudal" que dava o caráter historicamente necessário àquelas instituições, já que o grande domínio era o único capaz de oferecer alguma forma de segurança às pessoas e a seus bens. No entendimento de Smith, enquanto houvesse aquela circunstância, o morgadio e a primogenitura não poderiam ser considerados leis desarrazoadas. O problema foi a permanência delas em uma época posterior, "depois de cessarem as circunstâncias que lhes deram origem, circunstâncias essas que constituíam a única justificativa razoável de tais leis". Elas deixaram de ser razoáveis e, portanto, justificáveis, quando "as leis dos respectivos países passaram a oferecer segurança tanto às propriedades pequenas como às grandes" (idem, p.326).

Portanto, de acordo com seu raciocínio, tanto o morgadio quanto a lei de primogenitura não são, em si, instituições absurdas. O que as torna absurdas é a sua permanência em outra época histórica, a época burguesa. Depois que a unificação nacional e o fortalecimento do poder real criaram na Europa uma situação "em que as leis dos respectivos países oferecem segurança tanto às propriedades pequenas como às grandes", para que serviriam o morgadio e a primogenitura? $\mathrm{Na}$ formulação do economista escocês, apenas para a manutenção do "privilégio exclusivo que a nobreza tem no acesso aos grandes postos e honras de seu país" (idem, p.327).

Cessando, assim, as circunstâncias que lhes deram origem, aquelas instituições tornam-se apenas meios de manutenção de privilégios de uma classe, a nobreza, a qual, por sua vez, também perdera sua função social, a de proporcionar segurança num mundo caótico e conturbado pela ausência de um centro de poder estável.

Nessa nova situação de uma Europa em que as grandes monarquias unificadas haviam se consolidado, aquelas instituições medievais passaram a ser vistas por Smith como embaraços ao desenvolvimento da agricultura porque obrigavam, artificialmente, a transmissão da propriedade da terra unicamente para o filho primogênito do sexo masculino e impediam, nas gerações sucessivas, que tal propriedade fosse subdividida 
em propriedades menores por meio da partilha da herança entre todos os filhos. Se a primogenitura impedia a partilha da propriedade agrária por meio da herança, o morgadio impedia a mesma partilha por meio da alienação, doação ou legado, como já vimos linhas atrás.

Desta forma, aquela legislação agrária feudal não só contrariava o princípio da igualdade burguesa, segundo o qual todos os filhos têm igual direito à herança dos bens paternos, mas também perpetuava um tipo de propriedade menos rentável. No que se fundava essa opinião de Smith? Na idéia de que a pequena propriedade era mais rentável do que a grande, em razão da diferença de hábitos e de educação existente entre um pequeno proprietário plebeu e um nobre, senhor de um grande domínio. Vejamos, com as palavras do próprio Smith, como essa questão é colocada:

Em conseqüência do morgadio, não somente grandes áreas de terras incultas foram açambarcadas por determinadas famílias, como também excluiu-se .a possibilidade de dividi-la. Ora, é raro o caso de um grande proprietário de terras empenhar-se em melhorá-las. ... O melhoramento da terra com lucro, como todos os demais projetos comerciais, exige cuidado e atenção minuciosos a pequenas poupanças e pequenos ganhos, coisa de que muito raramente é capaz um homem nascido com grande fortuna, mesmo que por natureza ele seja frugal. A situação de tal pessoa a dispõe naturalmente a voltar-se mais para objetos de adorno, que agradam à fantasia, do que para o lucro, do qual tem tão pouca necessidade. Desde sua infância, os objetos de suas maiores preocupações são a elegância no vestir, a beleza de seus pertences, de sua casa, da mobília doméstica. ... Ainda restam, na Inglaterra e na Escócia, algumas grandes propriedades que continuaram sem interrupção nas mãos da mesma família, desde os tempos da anarquia feudal. Compare-se a situação atual dessas propriedades com a das terras dos pequenos proprietários da região e não haverá necessidade de outro argumento para convencer-se até que ponto essa grande extensão de terras é desfavorável à introdução de melhorias. (Smith, 1983, I, p.317-8)

Ora, impedindo a subdivisão da terra, o morgadio tornava-se um obstáculo intransponível para a penetração do capital produtivo na agricultura e, em conseqüência, para a adoção de novas tecnologias e de novas práticas administrativas no meio agrário.

Esclarecida, assim, a posição da Economia Política Clássica a respeito dessas instituições feudais que regulavam a posse da terra e suas regras jurídicas de sucessão e alienação, voltemos a analisar a posição de Cairu.

Atento às singularidades da formação histórica brasileira, Cairu procurou mostrar que, embora existissem em Portugal, instituições com características marcadamente feudais eram praticamente inexistentes no Brasil. Segundo ele, no Brasil 
existiam instituições que apenas remotamente guardavam alguma semelhança com o direito de primogenitura e com o morgadio e, mesmo assim, a quantidade de bens regulados por elas era insignificante para exercer alguma influência no desenvolvimento da agricultura. Ele diz isso em um de seus discursos no Senado:

No Brasil há poucos morgados ou bens vinculados com autoridade do Governo. O maior número é dos de bens encapelados, por disposição testamentária, que são sujeitos a encargos pios. Não sou informado dos morgados de todo o Império, é notório que o Morgado de Marapicú, desta Província do Rio de janeiro, pertence à distinta família do Conde de Arganti, que foi reitor e reformador da Universidade de Coimbra. Também é notório que o morgado da Torre, na Província da Bahia, é de antigo estabelecimento... (Cairu, 1829, p.88)

Essa observação de Cairu é corroborada por outro registro contemporâneo. O inglês Henry Koster, ativista liberal e revolucionário que viveu no Brasil no começo do século XIX, registra a existência destas propriedades rurais vinculadas. Entretanto, pela maneira vaga e rápida de abordar a questão, ele deixa subentendido que os bens vinculados não representavam grandes embaraços ao desenvolvimento da agricultura brasileira, principalmente porque não constituíam a forma dominante de propriedade rural:

Existe em Pernambuco alguns morgados, terras vinculadas, e creio que em Paraíba também e ouvi dizer que na Bahia havia muito. Há também Capelados ou terras de Capelas. Esses bens não podem ser vendidos, e por esse motivo ficam algumas vezes abandonados, e trazem menor interesse ao Estado que outros bens sob outras circunstâncias. O Capelado é constituído da seguinte forma: o proprietário lega uma parte de seus domínios ou rendas de suas terras e uma igreja escolhida, com o propósito de ter missas para sua alma ou outras obras de natureza desinteressada. Nessa situação, de acordo com a lei, o bem não pode ser vendido, de sorte que, se o beneficiado não é bastante rico para fazer ele próprio mover o engenho, o aluga a alguém que possua um número razoável de negros e o possa movimentar. (Koster, 1942, p.435)

Um estudo mais recente sobre legislação agrária no Brasil também confirma a apreciação de Cairu sobre a pouca expressividade do morgadio no meio agrário do Brasil, até sua extinção definitiva em 1835:

A lei dos morgados definia que os bens passassem indivisos ao filho mais velho. A abolição dessa lei, na realidade, veio corroborar uma prática já existente, pois foram raros os casos de morgadio no Brasil colonial. As propriedades eram, em geral, divididas entre os filhos e até mesmo as filhas, como dote. Essa forma era muito mais compatível com o sistema imperante no campo brasileiro, isto é, um 
sistema caracterizado pela mobilidade, pelo crescimento em extensão e pela disponibilidade de terras. (Silva, 1996, p.85)

Mesmo assim, Cairu não deixou de incorporar e expressar, ainda que de forma diluída, a crítica de Adam Smith a estas instituições de origem feudal. Acreditamos que por dois motivos. Primeiro, por uma questão de coerência e fidelidade teórica em relação a Adam Smith. Segundo, porque sua obra se refere, também, a Portugal, o que exige, certamente, um posicionamento crítico, embora moderado e cuidadoso, em relação àquelas instituições feudais que ainda existiam na Metrópole.

Esta crítica da sociedade feudal não ocupa muito espaço na obra de Cairu, ao contrário do que ocorre na obra de Adam Smith, mas mesmo assim não deixa de ser profunda. O pressuposto dessa crítica é de que, no feudalismo, uma parte considerável da sociedade, o clero e a nobreza, vive na preguiça e não se submete àquela lei natural que obriga o homem a trabalhar para subsistir, multiplicar e prosperar como espécie. No feudalismo, ainda, a pouca eficiência produtiva faz que os homens dependam basicamente das potencialidades da terra e não do trabalho humano para se produzir a riqueza social. As passagens seguintes mostram isso claramente:

Muitas são as conseqüências morais, econômicas e políticas, que se derivam do princípio de ser - o trabalho e não a terra, o fundo ou fonte da riqueza social. Ele extirpa a preguiça, como o maior flagelo das Nações; lança o fundamento da discreta divisão e franca circulação de quaisquer possessões e domínios, como o mais oportuno meio para o seu mais bem dirigido e produtivo trabalho possível, livrando-se o Estado de coutadas, vínculos e mãos mortas que estagnam em mãos avaras e pouco industriosas, os armazéns da subsistência e riqueza da sociedade e obstam que se experimente em todas as partes e tempos a exaltada energia e idôneo emprego de capitais dos indivíduos mais capazes de dar à agricultura a maior extensão e perfeição. Também convence o erro dos grandes proprietários e Nações, que tanto se empenham em abarcar, alargar e monopolizar territórios; sem atenderem que, não obstante essas vantagens, não pode haver grandes réditos sem pôr em movimento e boa direção muita quantidade de trabalhos, em virtude de proporcionados capitais, tanto os circulantes, para se pagarem os salários dos trabalhadores, avanços da cultura e os materiais das obras de qualquer gênero, como os fixos nas melhores benfeitorias rústicas e urbanas, instrumentos e vasos de terra e água e sobretudo o mais importante de todos os capitais, que são as acumuladas habilidades dos habitantes do país. (Cairu, 1956, p.165)

Percebemos, assim, que, na obra de Cairu, as instituições e costumes que se relacionam às propriedades feudais ou semifeudais são condenáveis em razão de vários aspectos: porque contribuem para perpetuar a avareza, a preguiça e a pouca indústria de 
seus proprietários, o que é um desrespeito flagrante ao que ele chama da lei natural que obriga todo homem ao trabalho; porque impedem a discreta divisão e livre circulação da propriedade da terra, eliminando, dessa maneira, a possibilidade de que outros homens mais capazes e produtivos empreguem seus capitais na agricultura; porque, enfim, estas instituições e costumes impedem que a agricultura tenha, por causa de todas as razões citadas, maior extensão, eficiência e perfeição.

É necessário observar, porém, que Cairu formula a crítica das instituições feudais dando destaque quase tão somente aos aspectos econômicos gravosos e irracionais destas, sem se preocupar muito em mostrar seus aspectos injustos e opressivos, como faz Adam Smith. Este, como já vimos, criticou tais instituições não somente pelo que elas representavam em termos de irracionalidade econômica, uma vez que impediam maior penetração do capital produtivo na agricultura, mas também pelo que elas representavam em termos de violação dos postulados da justiça burguesa, pois privilegiavam uma única classe ou um único membro da família como beneficiário da propriedade da terra, em detrimento dos interesses das demais classes e dos demais membros da mesma família em relação a esta propriedade.

Diante deste contexto, calcula-se que, pela lógica, diante de uma iniciativa concreta visando a eliminação destas instituições no Brasil, apenas duas atitudes poderiam ser esperadas de Cairu: que ele agisse, no mínimo, com indiferença ou, no máximo, que lançasse apenas um tímido apoio político a tal iniciativa.

Dizemos que estas seriam as mais prováveis atitudes políticas de Cairu porque levamos em conta justamente a sua crença de que o direito de primogenitura e o morgadio não representavam, de fato, qualquer sério embaraço ou desestímulo econômico-social ao desenvolvimento da agricultura brasileira. Abolir ou não tais instituições não seria, portanto, uma questão vital para a economia brasileira no entendimento de Cairu; daí a expectativa de que ele se comportasse com indiferença ou se posicionasse sem muita convicção íntima em relação ao assunto.

Não obstante, quando a questão foi apreciada no parlamento brasileiro, por iniciativa da minoria liberal radical, em 1829, Cairu não somente votou contra a abolição de tais instituições, contradizendo, aparentemente, suas crenças de economista político liberal, mas, além disso, articulou, com sua influência pessoal e com a eloqüência e erudição de seus discursos, a votação vitoriosa contra o projeto de abolição do direito de primogenitura e do morgadio (Armitage, 1981, p.189) ${ }^{4}$.

Como explicar tal paradoxo? 
Para nós, a explicação mais plausível estaria no pragmatismo e na prudência política, traços marcantes na trajetória de Cairu, sempre avesso ao radicalismo quando se tratava de reformar a sociedade. Nossa interpretação é de que, para além da avaliação de Cairu de que o morgadio não era um grande óbice ao desenvolvimento da agricultura no Brasil, a posição tomada por ele na ocasião foi ditada mais por considerações políticas. No conjunto de sua obra, Cairu manifestou mais de uma vez grande preocupação com a estabilidade e permanência do regime monárquico ilustrado entre nós. Residiria aí, em nosso entendimento, a chave para A explicação da posição de Cairu na discussão e votação da questão do morgadio no parlamento.

Quanto aos liberais radicais, narra-nos John Armitage que eles argumentavam precisamente no sentido de mostrar a impropriedade e o caráter inteiramente exótico, irracional e antinatural do direito de primogenitura e do morgadio no Brasil, considerando que nenhuma organização social semelhante à feudal jamais existira no Brasil (Armitage, 1981).

Mas se, como vimos, o apoio de Cairu em relação à permanência da primogenitura e do morgadio baseava-se, fundamentalmente, em razões políticas, o mesmo acontecia com os liberais radicais quando propunham a abolição das mesmas instituições. Com efeito, esclarece ainda Armitage, os parlamentares liberais radicais objetivavam, com o combate à lei da primogenitura e do morgadio, antes se precaverem contra a futura e hipotética criação de uma aristocracia hereditária e de um Senado vitalício a ser composto pelos membros dessa aristocracia do que prevenir mal algum existente (ibidem).

Depreende-se disso que a posição ostensiva dos liberais radicais contra aquelas instituições não se originava de uma tomada de consciência acerca do caráter econômico pernicioso destas em relação ao desenvolvimento daquilo que Cairu chama de Ativa Indústria ${ }^{5}$ no Brasil. Muito pelo contrário, como aponta novamente John Armitage, eles repudiavam as instituições econômicas e sociais tidas como antiliberais mais por um espírito de oposição ao Governo do que por uma convicção íntima sobre a matéria (ibidem). Tanto para Cairu como para os liberais radicais, a questão era, portanto, de caráter político e não econômico. O caráter político desse posicionamento sobre o morgadio precisa ser nuançado, porém, já que em Cairu permanece uma consideração de fundo econômico.

E aqui emerge uma grande diferença entre ele e os liberais radicais, que tomam posicionamento a partir de posições doutrinárias puras. Cairu, ao contrário, é 
pragmático, isto é, procura adaptar os princípios gerais que defende às circunstâncias especiais do momento histórico e das condições peculiares do país.

Em face da traumática experiência da Revolução Francesa e, também, por convicção derivada de sua formação em Coimbra e por influência da monarquia britânica, que ele julgava o mais bem-sucedido sistema de governo, Cairu foi um convicto defensor do regime monárquico ilustrado por julgá-lo a forma de governo mais adequada para se promover, sem sobressaltos, a Ativa Indústria. Por essa razão, adotou, na discussão sobre o morgadio e em outras circunstâncias semelhantes, uma posição aparentemente conservadora. Nesses e em outros casos, seu pragmatismo falava mais alto que qualquer outra consideração de ordem doutrinária pura. Para ele, a ação política determinada pelo radicalismo doutrinário poderia representar uma ameaça maior do que a sobrevivência de uma instituição vista com antipatia pelo próprio liberalismo econômico, do qual ele se considerava um porta-voz em terras brasileiras.

Assim, seu posicionamento sobre a primogenitura e o morgadio poderia ser resumido da seguinte maneira. Por um lado, acreditava que a sociedade brasileira nada tinha a ganhar com a abolição destas instituições justamente pelo fato de elas não representarem nenhum sério embaraço aos melhoramentos econômicos e ao atendimento do bem comum. Por outro, considerava que o prejuízo político era quase certo, pois a abolição do direito de primogenitura e do morgadio significaria a destruição de um instrumento de elevado valor simbólico para a manutenção da monarquia ilustrada. Com base no exemplo da monarquia inglesa, a ser imitado, e no da República Revolucionária francesa, a ser evitado, Cairu considerava a permanência de um corpo de nobreza, ao estilo britânico, um elemento essencial para a estabilidade da instituição monárquica.

Para ele, o Soberano deve ser o principal proprietário do país para que ele possa ter os meios e o interesse de dar a maior segurança possível às pessoas e propriedades de seus vassalos. As vastas propriedades da nobreza deveriam, também, ser preservadas, com determinadas limitações, porque elas servem de baluartes de todas as propriedades inferiores (Cairu, 1975, p.365-6).

De acordo com esse raciocínio, a existência tanto da propriedade do monarca como das propriedades dos grandes senhores deve ser condicionada a duas exigências básicas.

A primeira, que as propriedades tenham uma natureza econômica e social próxima da natureza reformada das grandes propriedades rurais inglesas, que nada mais 
são do que propriedades burguesas, apesar dos títulos nobiliárquicos, honrarias e rituais aristocráticos que a acompanham. Isso aparece claramente nos Estudos do Bem Comum:

No Tempo do Governo Feudal da Europa, um Grande Senhor não tinha em que despender a renda de suas herdades (toda consistindo em vasta colheita de produtos rudes de trigo, vinho, azeite, gado, lã, etc.), senão em manter proporcional número de rendeiros, escravos, e apaniguados, moradores em terras, que por isso viviam em absoluta servilidade, ou dependência; e em consequiência os tinham sob o seu poder e mando para invasão dos vizinhos, e rebelião aos Soberanos. Mas, desde que o comércio, e o progresso das artes superiores, especialmente pela introdução dos mais polidos países estrangeiros, entrou a multiplicar as obras de primor, dando esplêndida equipagem, vistosos móveis, casa magnífica, lauta mesa, e jóias preciosas; cada rico Proprietário, que, pelo seu orgulhoso egoísmo, deseja (quanto lhe é possível) gastar consigo todo o valor de sua renda; vendo que isso só era praticável indiretamente, por via do troco da sua anual colheita pela moeda da Praça, a fim de com ela ter a escolha da compra desses objetos, que entende serem os símbolos da Nobreza, Opulência, e Dignidade; logo despede as bocas inúteis dos criados e parasitos, e remete para o Mercado a quantidade do produto rude que excede as reais necessidades de sua pessoa e família. Assim os Nobres vieram a sustentar maior número de artistas e trabalhadores produtivos fora de suas terras; e a rústica suntuosidade dos campos cessou, e de converteu em elegante despesa nos artigos de indústria das cidades.

Por esta mudança de economia, deram mais certo, melhor e extenso emprego aos industriosos; mas perderam os braços dos serviçais, com que antes exerciam seus caprichos. Daí em diante, em vez de terem sob seu império gente servil, inerte, e desordenada, estenderam a classe da gente livre, habilidosa, e civil. Assim se fez a mais útil, e insensível revolução na polícia rural e municipal. (Cairu, 1975, p.404)

A segunda, que essas grandes propriedades da nobreza sejam reduzidas ao menor número possível, de modo que não impessa a existência das propriedades menores, acessíveis a todas as classes. Ele defende, portanto:

Divisão das terras, proporcionada, mas não excessiva, sem obstáculo à aquisição por todas as classes, com o menor possível número de que se dizem Bens Vinculados, Baldios, e de Mão-Morta, quanto seja compatível com a Constituição do Estado. (Cairu, 1975, p.363)

Não vendo problemas nestas grandes propriedades da nobreza, ele vai guardar a maior parte de suas energias para combater aquilo que ele denomina excessiva divisão das terras ou partilha de glebas. Ao leitor desavisado, poderia parecer que Cairu estava defendendo determinadas leis feudais e se opondo, de forma absoluta, ao que chamava de natural traspasso e às subdivisões das propriedades territoriais, pelos legítimos 
títulos de venda, doação, arrematação, herança, casamento e legado, o que não é verdade. Ao ver negativamente a excessiva divisão das terras, ele estava, na verdade, se opondo especificamente à experiência política da Revolução Francesa durante o período do Terror. Concretizou-se, nesse momento da ação dos revolucionários jacobinos, o projeto dos economistas e filósofos liberais radicais ao estilo de Rousseau, de parcelamento das terras entre milhares de camponeses e trabalhadores rurais.

Cairu apresenta duas justificativas para fundamentar sua oposição a esta partilha excessiva de glebas, por decisão política.

Uma delas, de natureza política, é que tal partilha introduz, inevitavelmente, um clima de insegurança e de comoção política na sociedade, o que pode vir a ser a precondição para a desorganização do sistema civil. Isso acontece porque esta artificial e forçada divisão de terras concretiza-se freqüentemente por meio da destruição daquelas propriedades que servem justamente de baluartes e antemurais a todas as propriedades inferiores: as vastas propriedades dos Grandes Senhores.

A outra justificativa, de natureza econômica, é que esta divisão excessiva das terras provoca o aumento da miséria no seio da população proletária e a extinção de várias indústrias úteis:

Mas, assim como a divisão do trabalho é perniciosa, sendo desmedida ... também não é menos prejudicial a excessiva divisão das terras, que degenere em partilha de glebas: porque se constituiria a população proletária, e por extremo miserável; e extinguiria inumeráveis sortes de indústrias úteis, que só se podem exercer nas Vilas e Cidades, em benefício não menos da gente do campo, em justas proporções, e para maior redito nacional, e progressiva indústria de todas as classes. (Cairu, 1975, p.366)

Segundo Cairu, portanto, se levada ao extremo, a partilha da terra atrairia a população urbana para o campo, provocando, conseqüentemente, o enfraquecimento das manufaturas citadinas. Esse enfraquecimento das manufaturas urbanas, por sua vez, se reverteria no enfraquecimento da própria agricultura, visto que as artes urbanas perderiam ou enfraqueceriam a capacidade de transformar os produtos primários da agricultura para atender às necessidades da população das cidades e, ao mesmo tempo, deixaria de contribuir para o aprimoramento das forças produtivas da agricultura por meio do fornecimento de insumos e máquinas. O que pareceria, assim, um conservadorismo de Cairu é, na verdade, uma defesa das condições mais favoráveis ao 
desenvolvimento integrado da produção burguesa, em todos os ramos da divisão social do trabalho, no início do século XIX.

Tais constatações nos levam a encarar com reservas a classificação de Cairu como um pensador passadista e conservador, como fizerem alguns estudiosos de sua obra. Classificando-o dessa maneira, sem nenhuma mediação, estes estudiosos ignoram, como mostraram Arruda e Novais (2003) e Pereira (1994), por exemplo, que Cairu foi, além de um crítico ferrenho do mercantilismo e do antigo regime, um dos artífices do estado nacional brasileiro no momento em que se esgotavam as possibilidades de o Brasil permanecer como Reino Unido de Portugal.

Classificando-o como passadista, esses estudiosos não conseguem perceber, também, que Cairu fazia não uma oposição absoluta e dogmática à reforma da sociedade colonial-escravista, mas sim uma oposição ao radicalismo jacobino como método e programa de transformação social. Não podemos nos esquecer de que Cairu justificava sua oposição política e teórica ao jacobinismo por duas razões básicas. Primeira, pelo excesso de violência e pela ação política destrutiva promovida por esta

corrente revolucionária durante a Revolução Francesa. Segunda, porque a desorganização social provocada pelo radicalismo jacobino teria gerado as condições para a ascensão de Napoleão Bonaparte, o personagem histórico que encarnava o oposto da liberdade política e econômica proposta pelos filósofos e economistas liberais do século XVIII.

\section{REFERÊNCIAS BIBLIOGRÁFICAS}

ARMITAGE, John. História do Brasil. São Paulo: Editora Edusp/Itatiaia, 1981.

ARRUDA Jose J. \& NOVAIS, Fernando N. Prometeus e Atlantes na Forja da Nação. Economia e Sociedade, Campinas, v. 12, n.2 (21), p.225-243, 2003.

HOLANDA, S. B. de. Raízes do Brasil. Rio de Janeiro: José Olympio, 1976.

CARVALHO, Darcy. Desenvolvimento e livre-comércio. (As idéias econômicas e sociais do Visconde de Cairu. Um estudo de história do pensamento econômico brasileiro). São Paulo: Instituto de Pesquisas Econômicas da USP, 1985. 
ELIAS, Norbert. O Processo Civilizador. Formação do Estado e Civilização. Apresentação de Renato Janine Ribeiro. Trad. Ruy Jungmam. Rio de Janeiro: Jorge Zahar Editor, 1993. v.2.

FENELON, D. Cairu e Hamilton: um estudo comparativo. Belo Horizonte, 1973. 180p. Tese (Doutorado em História) - Universidade Federal de Minas Gerais.

KOSTER, Henry. Viagens ao Nordeste do Brasil. Trad. e notas de Luiz da Câmara Cascudo. Rio de Janeiro: Cia. Editora Nacional, 1942.

LISBOA (Visconde de Cairu), José da Silva. Anais do Senado (Sessões de 1829). . Princípios de Economia Política. Rio de Janeiro: Editora Irmãos Pongetti, 1956.

Estudos do Bem Comum e Economia Política, ou ciência das leis naturais e civis de animar e dirigir a geral indústria e promover a riqueza nacional $e$ prosperidade do estado. Introdução de José de Almeida. Rio de Janeiro: Ipea/INPES, 1975.

MARTINS, Wilson. História da inteligência brasileira (1794-1853). São Paulo: Editora Cultrix, 1978. v.II

PAIM, Antônio. Cairu e o liberalismo econômico. Rio de Janeiro: Editora Tempo Brasileiro, 1968.

PEREIRA, José Flávio. Cairu revisitado: uma contribuição ao estudo do reformismo liberal. São Paulo, 1994. 335p. Tese (Doutorado em História) - Faculdade de Filosofia, Letras e Ciências Humanas da Universidade de São Paulo.

PEREIRA, Lupércio A. Limites históricos do pensamento abolicionista. Uma contribuição ao estudo do gradualismo adotado na abolição da escravidão no Brasil. Assis, Unesp, 1986 (dissertação de mestrado).

ROCHA, Antônio P. A economia política na sociedade escravista (um estudo dos textos econômicos de Cairu). São Paulo: Editora Hucitec, 1996, 167p.

SILVA, Lígia Osório. Terras devolutas e latifúndio. Efeitos da lei de 1850. Campinas: Editora da Unicamp, 1996.

SMITH, Adam. A Riqueza das Nações. São Paulo: Abril Cultural, 1983

TOCQUEVILLE, A. de. O Antigo Regime e a Revolução. Brasília: Editora da UNB, 1979. 
PEREIRA, José Flávio e PEREIRA, Lupércio Antônio. Juridical institutes, agrarian property and economic development in José da Silva Lisboa's thought (1829). História, São Paulo, v. 25, n. 2, p. 192-213, 2006.

\begin{abstract}
The aim of this article is to analyze the political position of José da Silva Lisboa, the Viscount of Cairu, on the debate that took place in the Brazilian Parliament in 1829 concerning to the abolition of two feudal juridical institutes that were inherited from Portugal: the law of primogeniture and the entail. According to Cairu, such institutes, which have made compulsory the transmission of the land property to the first-born male child keeping him from breaking the property into small parcels by alienation, have a very weak existence in Brazil, which has not endangered, therefore, neither the agriculture development nor the property democratization. However, when this matter was discussed by the Senate, Cairu has articulated the victorious election against the extinction of them, apparently denying his liberal ideas. We think that the reason for such paradox would be in Cairu's pragmatism and political prudence, who had always been against radicalism when he faced the social reform. This apparently antiliberal position is due to the fact that he considered those institutes important symbols for the maintenance of the enlightened monarchy in Brazil, which was a regime closer to the English political system, that Cairu thought should be followed, than to the radical French republican regime, that he believed should be avoided.
\end{abstract}

Keywords: Cairu, agrarian property, primogeniture right, Brazil.

Artigo recebido em 10/2006. Aprovado em 12/2206.

\title{
NOTAS
}

\footnotetext{
* Os autores são professores do Programa de Mestrado em História da Universidade Estadual de Maringá.

${ }^{1}$ Wilson Martins (1978) apresenta um julgamento da categoria inteligência de Cairu de forma muito próxima à de Déa Fenelon. Diz ele que Cairu expressa a preocupação política que dominou a geração que vivenciou a época da luta pela Independência: a definição e a implementação de um projeto político capaz de consolidar a emancipação política e a unidade nacional e de viabilizar um novo pacto social baseado na liberdade de comércio e no desenvolvimento da ciência e do trabalho voltados para a expansão manufatureira.

${ }^{2}$ A respeito da posição de Cairu sobre a escravidão e emancipação, ver o estudo de Lupercio Antonio Pereira sobre o pensamento abolicionista e sobre a estratégia gradualista adotada na abolição da escravidão no Brasil (Pereira, 1986).

${ }^{3}$ Como mostra Norbert Elias, mesmo no início do século XIV, quando a região que hoje corresponde à França estava em processo avançado de constituição do estado centralizado, era presente, ainda, na principal casa reinante francesa, a dos capetos, a preocupação com o não desmembramento da terra para se evitar a perda de poder da família: "O perigo que acompanhava o desmembramento do território em benefício de filhos mais jovens já era, portanto, claramente percebido, o que se confirma por grande número de pronunciamentos" (Elias, 1993, p.122).

${ }^{4}$ No Brasil, o morgadio só veio a ser extinto no período regencial, através de lei aprovada em 6 de outubro de 1835 (Silva, 1996).

${ }^{5}$ Ativa Indústria, para Cairu, significa trabalho humano eficiente, inteligente e rentável em qualquer atividade produtiva. Os requisitos gerais para o desenvolvimento dessa Ativa Indústria são os seguintes: trabalho livre, educação geral, liberdade de comércio e indústria, capitais disponíveis, democratização da
} 
propriedade da terra, governo zeloso da ordem pública e dos contratos, condições naturais favoráveis, relações de amizade e comércio com nações adiantadas, mercado amplo, etc. (Cairu, 1975, p.362-3). 